\title{
Development of Learning Materials Based on Guided Inquiry to Train Scientific Literacy in Primary School
}

\author{
Ike Khusniyawati, Suryanti, Tjandra Kirana \\ Universitas Negeri Surabaya \\ Surabaya, Indonesia \\ ike.kagawa.78@gmail.com
}

\begin{abstract}
This research is development of science learning materials based on guided inquiry. It modified 4D models on Human Digestive System material to train students' literacy. It used One Group Pretest-Posttest Design. The result showed that learning device consisting of learning plan, student activity sheet, and test scientific literacy deserves to be applied based on three criteria of expedience. First, valid assessment by experts reached average score 5. Second, the practical enforceability was $95.83 \%$ done, the result of scientific literacy ability was $94 \%$, students' response was positive, and students' activities indicate ongoing activities. The students' learning outcomes increased on pretest and posttest in high category based on $\mathrm{N}$ gain analysis, i.e. $\mathbf{0 . 8 3}$. The research concluded that material was valid, practical, and effective in increasing students' scientific literacy ability.
\end{abstract}

\section{Keywords-Learning Material; Guided Inquiry; Scientific} Literacy Ability; Primary School

\section{INTRODUCTION}

Entering the 21 st century the mastery of science and technology becomes the key to the success of a nation. It becomes a benchmark of the progress of a nation in the global competition arena. Science education as part of education is generally responsible and important in shaping students with active, innovative, and global competitive skills in accordance [1] about the standard learning process that states that the learning process in the educational unit held in an interactive and inspiring. Science education is also expected to be the main foundation of education as a vehicle for students to be more familiar with science contextually and implement it in everyday life [2]

Science and technology are progressing rapidly. Everyone is required to understand the environment, health, economy, and other problems faced by modern society. [3] Science literacy can contribute to life and can understand the natural world, improve human interaction with nature, society, and personal. Scientific literacy competencies include lifelong learning; including teaching equip students for further study and use the knowledge to make ends, therefore, scientific literacy becomes a must for every student to learn it.

Research on the ability of students' science literacy on an international scale organized by Trends in International Mathematics and Science Study (TIMSS) for grades IV and VIII showed a decrease in achievement that in 2007 got a score of 427, while in 2011 decreased to 406. Other studies held by the Organization for Economic Cooperation and Development (OECD) [4] through the Program for International student Assessment (PISA) on students' science literacy data obtained in 2009 with a value of 383 and 2012 with a value of 382 . Based on the results of these two studies concluded that the literacy skills Indonesian students decline year by year, even their literacy level is below the international standard average of 500, thus low student literacy can be one of the illustrations that science learning in Indonesian schools needs improvement [5].

The results of field studies and interviews conducted by researchers on some teachers and students in one of the primary schools in Surabaya turned out that students have not learned actively and have not been able to construct their knowledge on science learning process in school. Some teachers recognize that science learning in some materials is done by direct explanation from the teacher. Students are less introduced scientific way of work and accustomed to be given technique of drill and memorize in problem-solving or problem-solving. Teachers in the elementary school still find it difficult to develop learning tools which is in line with the demands of the 2013 curriculum [6] . Improving the learning process by developing learning tools that allow students to discover their own knowledge is one of the most fruitful attempts to improve student science literacy.

One of the learning models that provides an opportunity for students to actively develop conceptual understanding by combining their knowledge with reasoning and thinking skills is inquiry learning [7]. According to Piagets cognitive developmental theory, children aged 7 until 11 the year is at the stage of concrete operational development, in which case students are able to think logically and can connect the dimensions of each other but cannot think abstract, so they need guidance and intermediaries to think abstract and reasoning. Students can concentrate on building new knowledge and learning with guidance on useful strategies in each stage of the inquiry process [8], thus the guided inquiry learning model is expected to be appropriate for applying to elementary students.

The science literacy assessment in the Program for International Student Assessment (PISA) emphasizes real-life 
issues (OECD ) [9]. Human digestive system material is considered important in science literacy because: (1) Class five teacher in one primary school in Surabaya informs that the students' learning outcomes are still low on this material and students often find it difficult to deal with similar science materials, this is possible because their science knowledge is poorly literate. (2) Literacy skills and good learning outcomes can be used as a basis for understanding the environment and solving problems especially those closely related to science in the future.

The literacy learning, especially in the field of SD science is currently being encouraged, while researching the development of the device with guided inquiry learning that is oriented towards the increase of science literacy has never been done. Based on the background, the researcher intends to conduct research to develop a guided inquiry learning model device. The results of this study are expected to provide benefits in the form of development of learning devices in guided inquiry model which is valid, practical, and effective in increasing students' scientific literacy ability.

\section{METHOD}

This research is a study of learning tool development using guided inquiry model to trace the ability of science literacy of elementary students with digestive system material. Developed tools include: syllabus, lesson plan, student teaching materials, student worksheet, and science literacy test.

Research subjects in this study are students of grade $\mathrm{V}$ Iskandar Said Elementary School Surabaya amounted to 12 students. The location of this research is SD Iskandar Said Surabaya which is located at Jalan Kendangsari, Kelurahan Kendangsari, Kecamatan Tenggilis Mejoyo, Surabaya City.

Researchers use 4D model in three stages only, namely: define, design, and develop. The fourth stage, ie disseminate not done by researchers.

The research design used to test the learning device is using the One Group Pretest-Posttest Design. Students are given a pretest to find out the initial state of students' literacy skills. The study design is described as follows:

TABLE I

ONE GROUP PRETEST-POSTTEST DESIGN

\begin{tabular}{|ccc|}
\hline & & \\
Pretest & Treatment & Posttest \\
$\mathbf{O}_{1}$ & $\mathbf{X}$ & $\mathbf{O}_{2}$ \\
\hline
\end{tabular}

Instruments used in this study are as follows: 1. Observation sheet, 2. Test sheet, 3. Questionnaire, 4. Validation sheet. Observation sheets are used to measure teacher's implementation in learning, the test sheet is used to measure the success of the students 'science literacy skills, the questionnaire is used to measure students' responses to learning execution and validation sheets are used to measure the validity of instructional tools with guided inquiry models. Analysis of data processing in this study using quantitative qualitative descriptive analysis techniques

\section{RESULTS AND DISCUSSION}

The results of the research will be described into three parts, namely: 1. Validity of the learning materials with guided inquiry model, 2. The practicality of the learning materials with guided inquiry model 3 . The effectiveness of learning materials based on guided inquiry.

The validity of the learning materials with guided inquiry can be seen from the expert's assessment of the quality of the learning materials with the guided inquiry model, the experts judgment can be seen in the table below:

TABLE II. VALIDITY OF THE LEARNING MATERIALS BASED ON GUIDED INQUIRY MODEL

\begin{tabular}{|c|c|c|c|c|}
\hline No & Validator & Score & Percentage & Category \\
\hline 1 & Validator 1 & 3.88 & $96.9 \%$ & $\begin{array}{l}\text { Can be used with } \\
\text { little revision }\end{array}$ \\
\hline 2 & Validator 2 & 3.67 & $93.2 \%$ & $\begin{array}{l}\text { Can be used with } \\
\text { little revision }\end{array}$ \\
\hline
\end{tabular}

From the data in table II, validation of learning materials with guided inquiry based on the above can be concluded that the guided inquiry-based learning materials are very feasible to use because the results of the assessment experts show guided inquiry-based learning materials can be used with a little revision.

The next result is the practicality of learning materials based on guided inquiry, the practicality of learning materials based on guided inquiry can be seen from two assessments, namely: assessments of the implementation lesson plan and student activities.

TABLE III.

THE OBSERVER ASSESSMENT OF LEARNING ACTIVITIES

$\begin{array}{cccc}\text { Meeting } & \text { Score } & \text { Percentage } & \text { Category } \\ 1 & 36 & 90 \% & \text { Very high } \\ 2 & 36 & 90 \% & \text { Very high } \\ 3 & 38 & 95 \% & \text { Very high } \\ \text { Average } & 37 & 92 \% & \text { Very high }\end{array}$

From the table above, can be seen the results of the assessment of the way of learning using the of learning materials based on guided inquiry by observer shows average score 37 with percentage $92 \%$, indicating that the practicality of learning materials based on guided inquiry gets very good predicate used in learning.

The next result is the effectiveness of learning materials based on guided inquiry is the effectiveness of learning materials based on guided inquiry can be seen from two assessments, namely: the result of science literacy ability test and students response.

Improved literacy skills of science using material that have been developed on the material "Digestive Organs in 
Humans". Science literacy indicators studied include: identifying scientific issues, explaining scientific phenomena, and using scientific evidence can be seen in table IV below:

\begin{tabular}{|c|c|c|c|c|c|c|c|}
\hline \multirow{2}{*}{ No } & \multirow{2}{*}{$\begin{array}{c}\text { Students } \\
\text { Code }\end{array}$} & \multicolumn{3}{|c|}{$\begin{array}{l}\text { TABLE IV } \\
\text { Score }\end{array}$} & \multirow{2}{*}{$\mathbf{P}$} & \multirow{2}{*}{$\begin{array}{l}\mathrm{N}- \\
\text { Gain }\end{array}$} & \multirow{2}{*}{ Category } \\
\hline & & Pretest & $\mathbf{P}$ & Posttest & & & \\
\hline 1 & A1 & 50 & $\mathrm{D}$ & 85 & B & 0.70 & High \\
\hline 2 & A2 & 35 & D & 85 & C & 0.77 & High \\
\hline 3 & A3 & 40 & $\mathrm{D}$ & 86 & $\mathrm{C}$ & 0.76 & High \\
\hline 4 & A4 & 40 & $\mathrm{D}$ & 85 & B & 0.75 & High \\
\hline 5 & A5 & 40 & $\mathrm{D}$ & 75 & $\mathrm{C}$ & 0.58 & Medium \\
\hline 6 & A6 & 40 & $\mathrm{D}$ & 85 & B & 0.75 & High \\
\hline 7 & A7 & 35 & $\mathrm{D}$ & 85 & B & 0.77 & High \\
\hline 8 & A8 & 30 & $\mathrm{D}$ & 80 & B & 0.71 & High \\
\hline 9 & A9 & 40 & $\mathrm{D}$ & 85 & B & 0.75 & High \\
\hline 10 & A10 & 45 & $\mathrm{D}$ & 85 & B & 0.77 & High \\
\hline 11 & A11 & 45 & $\mathrm{D}$ & 85 & $\mathrm{C}$ & 0.76 & High \\
\hline 12 & A12 & 20 & $\mathrm{D}$ & 85 & $\mathrm{C}$ & 0.77 & High \\
\hline
\end{tabular}

Table IV shows that instructional tools of inquiry are guided to increase the literacy of science of elementary school students which is marked by improvement of score between before and after learning. The average of students who categorized high is the value of $\mathrm{N}$-Gain $>0.7$ whereas student of N-Gain $0.3-0.7$ is categorized as being [10]. Table 4.11 shows the value of N-Gain $0.45-0.77$. Science literacy test scores are presented in graphical form below:

DIAGRAM I

THE RESULT OF SCIENCE LITERACY ABILITY TEST

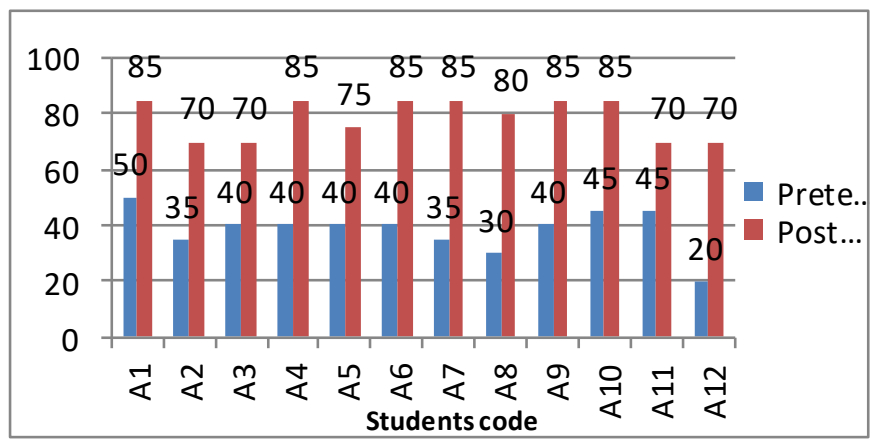

Students' responses are the students' opinions of interest, feelings of happiness and renewal, and ease of understanding the components that include student textbooks, activities in LKPD, learning atmosphere, how to teach used. Results of student response analysis on the category "yes" with percentage $91.67 \%-100 \%$, while the criteria "no" with percentage $8.33 \%$. Recapitulation of student's overall questionnaire results can be seen in diagram II:
DIAGRAM II

STUDENTS RESPONSE

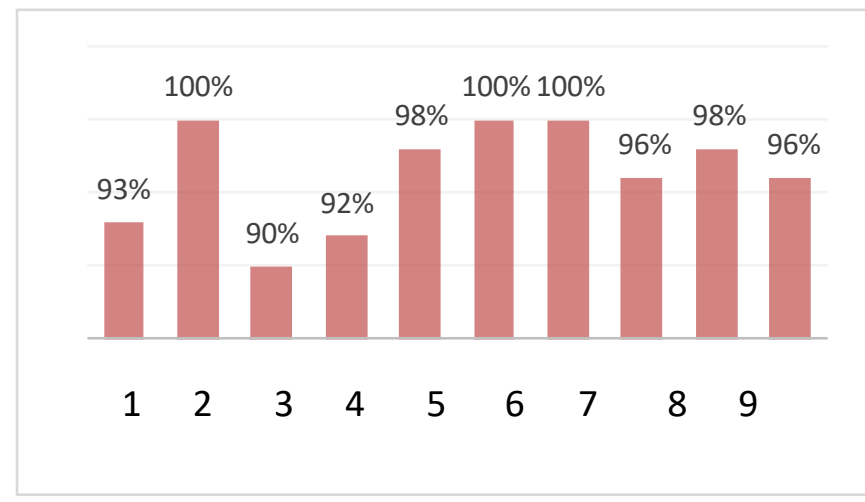

CONCLUSION

Based on the analysis of the results of the students literacy test and the student' responses to learning using the learning materials based on guided inquiry, it can be concluded that the learning materials based on guided inquiry is practically used in grade five elementary school learning.

\section{ACKNOWLEDGMENT}

Thank to various parties who assist in the preparation of this research, namely:

1. Prof. Dr. Ismet Basuki, M.Pd, as the Director of State University of Surabaya.

2. Dr. Hendratno, M.Hum, as the Chairman of Basic Education Program of Postgraduate Program of Universitas Negeri Surabaya which has given ease in completing this paper;

3. Prof. Dr. dr. Tjandra Kirana, Sp. And, as a supervisor I who has provided guidance, direction, and knowledge to complete this comprehensive paper;

4. Dr. Suryanti, M.Pd as a Supervisor II who patiently provides guidance, direction, and knowledge to complete this comprehensive paper;

5. All lecturers on the guidance that has been given during the researcher follow the lectures in post graduate Elementary Education Graduate Program State University of Surabaya.

6. Friends on the Master Program of Elementary Education of Postgraduate Program of Universitas Negeri Surabaya which has assisted and provided input to the researcher, and all the people who have helped to complete the research.

\section{REFERENCES}

[1] P. No, "Tahun 2016," Standar Isi pendidikan Dasar dan Menengah yang memuat tentang Tingkat Kompetensi dan Kompetensi Inti Sesuai dengan Jenjang dan Jenis Pendidika tertentu.

[2] L. Permendikbud, "Peraturan Menteri Pendidikan dan Kebudayaan Republik Indonesia Nomor 20 Tahun 2016 Tentang Standar Kompetensi Lulusan Pendidikan Dasar dan Menengah," Jakarta: Menteri Pendidikan Nasional, 2016. 
[3] H. Etzkowitz and L. Leydesdorff, "The dynamics of innovation: from National Systems and "Mode 2" to a Triple Helix of universityindustry-government relations," Research policy, vol. 29, pp. 109 $123,2000$.

[4] O. Pisa, "Assessment and Analytical Framework Mathematics, Reading, Science, Problem Solving and Financial Literacy, 2013," ed, 2012.

[5] H. Afkhami, "Saving water in lesson books of schools," Journal of global communication, 2008

[6] S. Dibaei and A. LAHIJANIAN, "Exploration of Environmental Education in Curriculum of Guidance Schools," 2009

[7] S. Magnusson, J. Krajcik, and H. Borko, "Nature, sources, and development of pedagogical content knowledge for science teaching," in Examining pedagogical content knowledge, ed: Springer, 1999, pp. 95-132.
[8] C. C. Kuhlthau, L. K. Maniotes, and A. K. Caspari, Guided inquiry: Learning in the 21st century: Learning in the 21st century: $\mathrm{ABC}$ CLIO, 2015.

[9] A. Ray and W. Margaret, PISA Programme for international student assessment (PISA) PISA 2000 technical report: PISA 2000 technical report: oecd Publishing, 2003.

[10] R. Hake, "American Educational Research Association's Division D, Measurement and Research Methodology: Analyzing Change/Gain Scores," USA: Wooland Hills, 1999. 